\title{
The VIII International Geological Congress, Paris 1900
}

Escuela Técnica Superior de Ingenieros de Minas-Universidad Politécnica de Madrid. E-mail: octavio.puche@upm.es, luisfelipe.mazadiego@upm.es, and p.kindelan@upm.es

France wanted to be the world centre of science and culture at the time of the Universal World Exhibition in 1900 and therefore welcomed several international congresses to Paris that year, including the VIII International Geological Congress. Some of the participants and organisers of this meeting are described and the participants and contributions are analysed by country. Topics in physical geography, tectonics and mineral deposits attracted particular attention. The main Congress themes are described and details of the numerous field excursions are also provided. No major scientific advances occurred as a result of the Congress but it provided the opportunity for valuable exchanges of information and ideas and impetus to several fields.

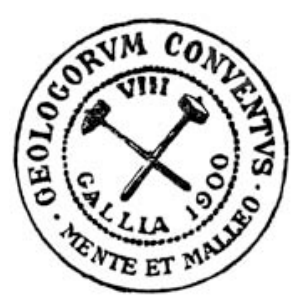

Figure 1 VIII International Geological Congress logo, Paris, 1900.

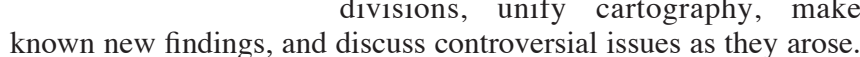
The Latin motto for the conferences in fact suggested these goals: 'mente et malleo' ('with mind and hammer').

In 1900, the Congress returned to its city of origin, Paris. The previous meeting had been held in St Petersburg (Russia) in 1897, chaired by the petrologist Alexander Petrovich Karpinsky (1846-1936), and it was decided that the next 'encounter' would take place in the French capital (Anon., 1899).

The French geologists set up an organizing committee, which, at its opening meeting, filled the executive posts and drew up a list of potentially suitable candidates for the effective development of the Congress. The committee was formed by sixty eminent geoscientists, who laid the foundations for the organization of the meeting (i.e. place, dates, permanent exhibitions, excursions, and so on), holding meetings on 11 January, 23 February and 13 April, 1898. Then, in 1899, the first circular was issued, including all this information. Although most of the leading French geologists were appointed to the committee, a few were omitted, such as Joseph Blayac and Louis Gentil (1868-1925), compilers of the Algerian geological map (1900), Léon Pervinquière, Alfred Dereims. The latter did not attend the Congress since he was exploring in West Africa at the time (cf. Gómez Alba, 1992).

On Thursday 16 August 1900, at 4 p.m., the formal opening session of the Eighth International Geology Congress took place in

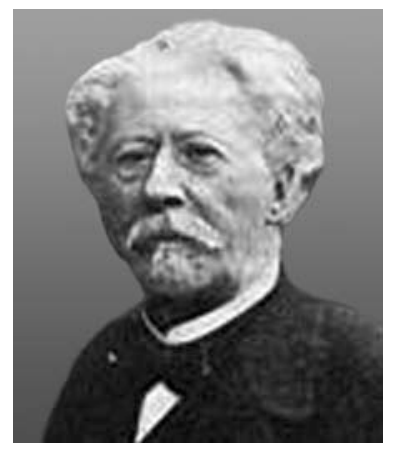

the Conference Palace of the Paris Universal Exhibition in Place de l'Alma. The ceremony was led by the Conference Chair, Albert Gaudry (1827-1908). He was a palaeontologist and professor at the Natural History Museum and had been ViceChairman of the first International Geology Congress (Ellenberger, 1970) (Figure 2). The Congress Secretary was the naturalist and former President of the Société Géologique de France, Charles Barrois
Figure 2 Albert Gaudry.

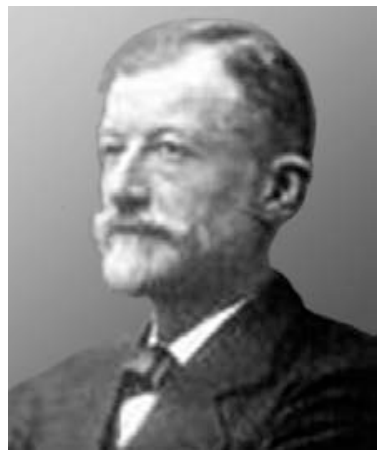

Figure 3 Charles Barrois. (1851-1939) (Figure 3). Two distinguished vice-presidents collaborated with them: Auguste Michel-Lévy (1844-1911), a renowned petrologist and chair of the French Geological Map Commission (Figure 4), and Marcel Bertrand (1847-1907), a tectonicist and Professor at the École des Mines in Paris (Figure 5). Others who participated in the organization were, for example, the sedimentologist and stratigrapher Lucien Cayeux (1864-1944), a disciple of Jules Gosselet in Lille, petrologist and head of geology at the École des Mines from 1907, Armand Thévenin (18701818), a well-known palaeontologist at the Natural History Museum, and Philippe Thomas (1843-1910) who had served in the army and discovered phosphate deposits in North Africa and at that time was director of graphic work for the French Geological Map Commission. The Treasurer was Léon Carez, editor of Annuaire de géologie and an authority on Pyrenees geology.

Gaudry and Barrois had worked outside France on several occasions and had contacts with other foreign geologists, and as Thévenin pointed out in Gaudry's obituary: "[h]e had the good fortune to chair the International Geological Conference held in Paris (1900) and feel the friendliness of geologists from other parts of the world, which had over a long time, grown out of the great courtesy always extended to him in his trips around Europe and America" (Thévenin, 1910).

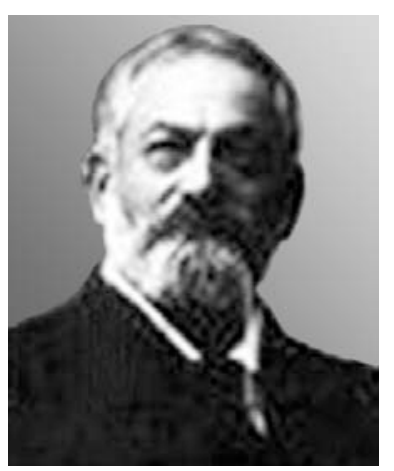

Figure 4 Auguste Michel-Lévy.

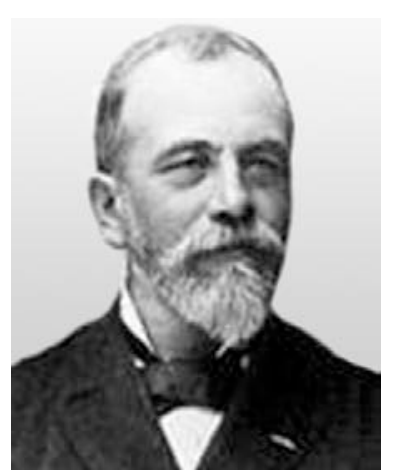

Figure 5 Marcel Bertrand. 


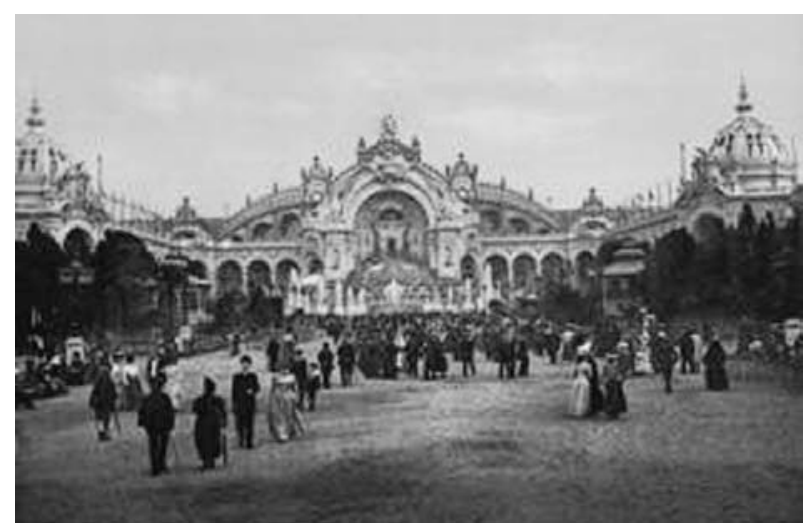

Figure 6 Paris Universal Exhibition, Electricity Palace.

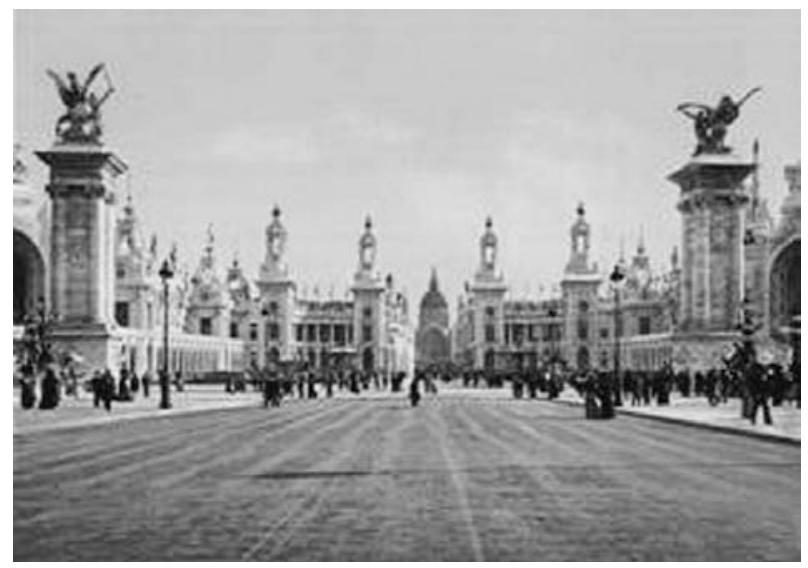

Figure 7 Paris Universal Exhibition, Alexander III Bridge.

The Paris Universal Exhibition had been opened on 14 April 1900. Electricity was undoubtedly the main star of this event, with the exhibition being lit by 12,000 bulbs. Other attractions were a reproduction of the Trans-Siberian Railway, simulating a trip from Peking to Moscow; the cinéorama with its circular screen and ten simultaneous projectors (but which soon had to be closed because of the risk of fire); the mareorama, simulating a trip through the Mediterranean, etc. These attractions were exhibited in a series of buildings in the art noveau style (Figures 6 and 7).

The Universal Exhibition coincided with a series of other events, such as the Second Olympic Games, where Pierre Frédy, Baron of Coubertain (1863-1937), a man of French origin, intervened to make the sporting event take place in Paris at the same time as the Exhibition. Other congresses were also held: for example, the Metallurgical Mining International Congress (18-23 June), the XIII International Medicine Congress (29 August), the Second International Mathematical Congress (6-12 August), the International Electricity Congress (18-25, August), the International Congress of

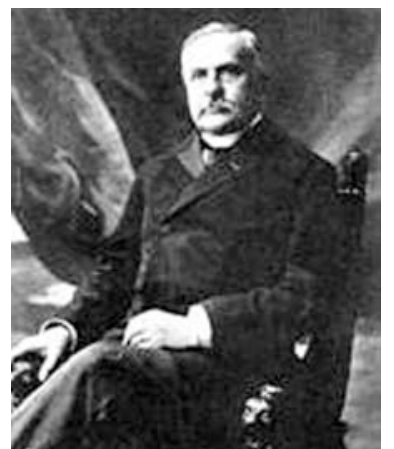

Figure 8 Albert de Lapparent, President of the Société Géologique de France.
Anthropology and Prehistoric Archaeology (18-25 August), the V Congress of the Second International (1889-1916), at which the International Socialist Bureau was founded, and so on and so forth. As the mining engineer Albert Auguste Cochon de Lapparent (1839-1908), President of the Société Géologique de France (Figure 8), rightly affirmed: "It was just impossible that the 1900 Exhibition and the International Geological Congress were not a manifestation of the same spirit" (Anon., 1901). The Geological Congress members had free access to the Exhibition.

The Société Géologique de France, which had participated in all the preparations for the Congress, had reached its seventieth anniversary and it was decided to commemorate this by holding a special meeting to coincide with the Congress. A previous special meeting had been celebrated in 1867, chaired by the Belgian geologist Jean Baptiste Julien d'Omalius d'Halloy (1783-1875), to coincide with the Universal Exhibition that year. There was a festive atmosphere in the special session of 1900, which included:

1. A reception offered to the Congress members in the Society's new premises (L'Hôtel des Sociétés Savantes) on the same day as the Congress opening. There was electricity to illuminate the event and the flags of the countries represented by those attending the Congress were raised, flanked by the French flag. The reception opened with a speech by the Society's President; and beverages were served.

2. Field trips were organized by the Congress to the environs of Paris, additional to those planned by the Congress's organizing committee to various places in France. The Society's excursions were led by the mineralogist and former President, Gustave Dollfus (1850-1931) and the mining engineer Léon August Janet (1861-1909), who was the Society's Vice-President and Treasurer at that time (Figure 9).

In the course of his address at the reception, de Lapparent said that the Society's greatest adornment was Albert Gaudry, who had been its President on three occasions. De Lapparent underscored the relationship between the Congress and the Société Géologique de France, referring to the close links between the two bodies (Anon., 1901). At that time, the Society had 520 members (Gaudant, 2007), a large number of whom participated in the Paris Congress (1900).

At the Society's meeting after the Congress on 5 November 1900 , Gaudry thanked the Society for its support and stated that there

\begin{tabular}{|c|c|c|}
\hline & $\begin{array}{l}\text { MExanks } \\
\text { INscruts }\end{array}$ & $\begin{array}{l}\text { Memane, } \\
\text { PMesexts }\end{array}$ \\
\hline Algérie-Tunisic $\ldots \ldots \ldots \ldots \ldots$ & 8 & 4 \\
\hline Allemagne. . . . . . . . . . & 124 & so \\
\hline Alsace-Lorraine $\ldots \ldots \ldots \ldots$ & 14 & 4 \\
\hline Argentine (République) . . . . . . . & 2 & $i$ \\
\hline 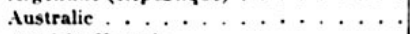 & 3 & 2 \\
\hline Autriche-Hongric $\ldots \ldots \ldots \ldots \ldots$ & 45 & 33 \\
\hline Belgique. . . . . . . . . . . . & 38 & 23 \\
\hline Brésil $\ldots \ldots \ldots \ldots \ldots \ldots$ & 1 & o \\
\hline 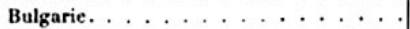 & 1 & 1 \\
\hline 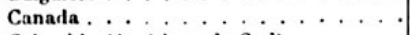 & 12 & 5 \\
\hline Colombie (Amérique du Sud) . . . . . & 1 & o \\
\hline Danemarck . . . . . . . . . & 2 & o \\
\hline 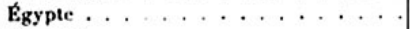 & 4 & 1 \\
\hline 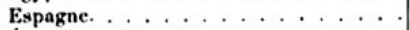 & 6 & 2 \\
\hline États-Unis d'Amérique. . . . . . . . & 69 & 24 \\
\hline France $\ldots \ldots \ldots \ldots \ldots$ & 400 & 16; \\
\hline Grande-Bretagne. . . . . . . . & 45 & 17 \\
\hline 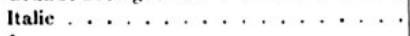 & 43 & 22 \\
\hline 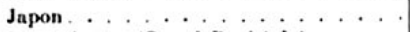 & 4 & 4 \\
\hline Luxembourg (Grand Duché de) . . . . & $i$ & o \\
\hline Mexique. . . . . . . . . & 3 & 3 \\
\hline Monaco (Principauté de) $\ldots \ldots \ldots \ldots$ & 1 & o \\
\hline 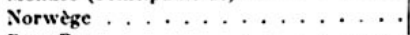 & 5 & 5 \\
\hline Pays-Bas $\ldots \ldots \ldots \ldots \ldots$ & 6 & 5 \\
\hline Portugal. $\ldots \ldots \ldots \ldots \ldots$ & 4 & 2 \\
\hline Républ:que Sud-Africaine. . . . . . . . . & 1 & o \\
\hline 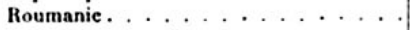 & 13 & 9 \\
\hline Russic. . . . . . . . . . . & 63 & 36 \\
\hline 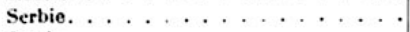 & 2 & $\mathrm{I}$ \\
\hline 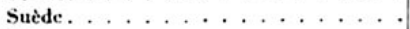 & 4 & 3 \\
\hline Suisse. . . . . . . . . . & ai & $z$ \\
\hline Totaux. & 1.016 & $46 t$ \\
\hline
\end{tabular}

Figure 10 Countries represented at the Congress. 


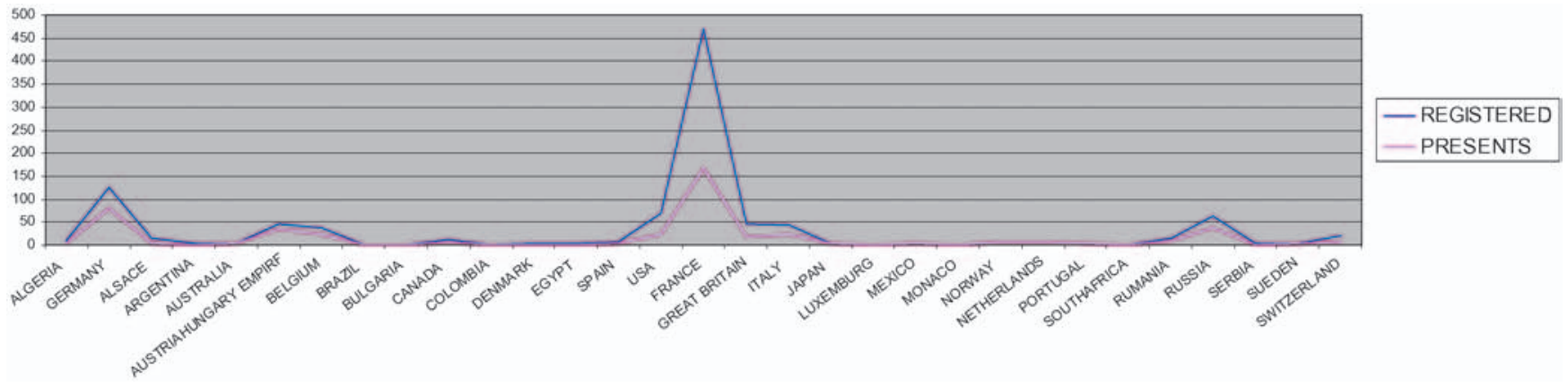

Figure 11 Distribution of Congress enrolments and participants according to nationalities.

had been 1,025 people registered at the conference, a significant number (Bulletin de la Société Géologique de France, 1901, v. 28, p. $805)$, which more than tripled the 310 participants of the previous Paris Congress in 1878 (Vai, 2004). Among the 1,025 people registered were the wives of some members as well as representatives of companies and scientific societies, such as the Société Géologique du Nord and the Société Géologique de France. As Gaudry pointed out in his opening address: "I have never before seen so many scientists gathered together, to whom geology, palaeontology and mineralogy owe their immense progress made in this century" (Gaudry, 1901). There were scientists from twenty-seven countries, comprisding Argentina, Australia, the Austro-Hungarian Empire, Belgium, Brazil, Bulgaria, Canada, Colombia, Denmark, Germany, Italy, Japan, Mexico, Monaco, The Netherlands, Norway, Portugal, Romania, Russia, Serbia, South Africa, Spain, Sweden, Switzerland, the United States and the United Kingdom as well as a large number of French geologists. There were also participants coming from what are now independent countries, such as Bosnia and Estonia (see Figures 10 and 11).

It is worth noting from the table and graph above that $47 \%$ of the participants came from France, the organizing country, followed by Germany with $12 \%$. However, only 461 members participated

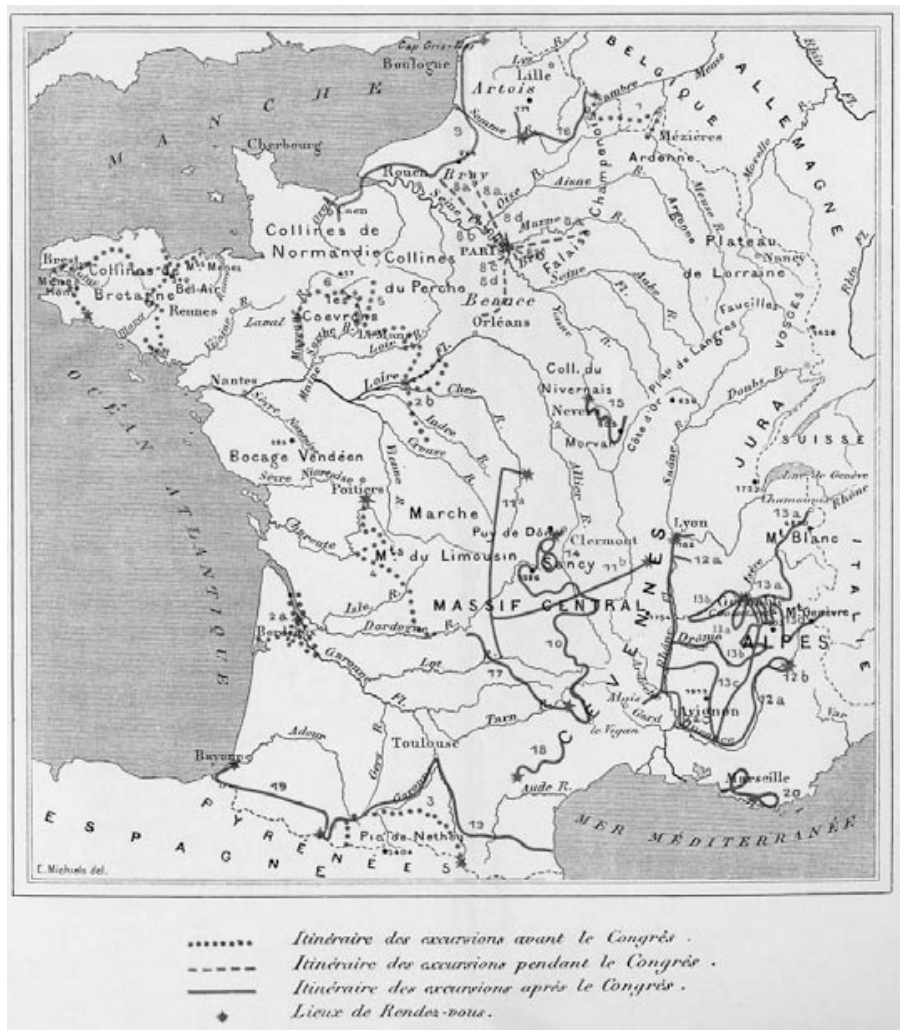

Figure 12 Map showing the Congress field excursions. actively (about 45\%), a large proportion of whom were French (167, about $36 \%$ ).

\section{The field excursions}

The organizing Committee arranged two types of field trips: 'general', which were open to all people who had attended the conference; and 'special', restricted to geologists interested in the specific subject of the trip, with a maximum of twenty people. The former ('general') followed the following routes: the Paris Basin and the principal fossil deposits of the area; a ten-day trip to Boulogne (Boulonnais) and Normandy; and another ten-day trip to the French Central Massif. The latter ('special') trips occupied between four and twelve days and followed these routes: Ardennes, Picardy, Brittany, Mayenne, Touraine (2), Morvan, Commentry coal basins, Decazeville and the Puys mountain range, Charentes, Bordeaux basin, Lower Alps, Dauphiné Alps and Mont Blanc, Pelvoux massif (Higher Alps), Monte Ventoux and Lure Mountain, Lower Provence, Black Mountain and the Pyrenees (2) (see Figure 12). These excursions were sometimes divided into different stages with various specialists as guides (Anon., 1900).

By the end of the Congress, forty excursions had been undertaken throughout the territory of France, in which forty-three of the country's best geologists had participated. Among these were Wilfrid Kilian (1832-1925), Professor of Geology at Grenoble University who succeeded the founder of alpine geology Charles Lory (1823-1889), the structural geologist from the Ecole des Mines, Marcel Bertrand (1847-1907), and Victor Paquier (1870-1911), a palaeontologist, and disciple and collaborator of Kilian at Grenoble.

\section{Pre-Congress excursions}

Eight such excursions were undertaken, centred on:

1. Stratigraphy and palaeontology of the Cambrian and Devonian periods of the Ardennes as well as on a series of studies carried out on the local metamorphism of this region (6-14 August). The party was led by Jules Gosselet (1832-1916), a professor in the Faculty of Sciences in Lille, a teacher of Charles Barrois, and founder of the Société Géologique du Nord (1870) (Figure 13).

2. Stratigraphy and palaeontology of the Cretaceous of Gironde Touraine (3-14 August), led by Emmanuel Fallot (1857-1929), a professor at Bordeaux University.

3. Crystalline rocks and contact metamorphism in the Pyrenees (4-14 August), led by Alfred Francoise Antoine (1863-1948), petrologist and professor at Paris Museum of Natural History.

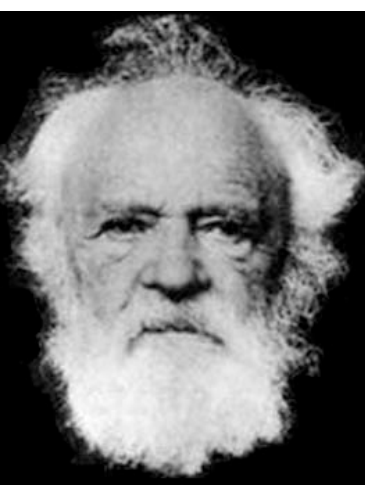

Figure 13 Jules Gosselet. 
4. The Jurassic and Cretaceous Periods of Aquitania (5-14 August) with their rich fossil deposits, led by Philippe Glangeaud (1866-1930), a lecturer in geology at Clermont Ferrand.

5. Stratigraphy and palaeontology of the Turonian of the Touraine region and the Cenomanian of the Le Mans region (5-14 August), led by Marie Félix Albert Durand Grossoure (1849-1932), a mining director from Bourges.

6. An excursion centred on Mayenne (9-14 August), and particularly on the study of the geological cross section in the Ante-Hercynian terrains of the Laval Basin as well as the granites and other igneous rocks of Coëvrons. It also involved the study of the relationship between the Mesozoic and the Cenozoic with the underlying Palaeozoic. The party was led by Daniel Victor Oehlert (1849-1920), a palaeontologist and collaborator in the compilation of the 'Geological Map Commission of France'.

7. The Palaeozoic of Brittany (4-14 August), and particularly its contact metamorphism as well as the volcanic massifs of Trégorrois and Menez-Hom. This group was led by Barrois.

8. Mineral and metalliferous

deposits of the Central Plateau (6-10 August). This excursion was led by Louis de Launay (1860-1938), Professor at the École des Mines (Figure 14).

\section{Post-Congress excursions}

\section{General field excursions}

Two general field excursions were undertaken:

1. Boulonnais and Normandy, led by a number of geologists, e.g. Gosselet, Munier-Chalmas, Pellat, Rigaux, Bigot and Cayeux (31 August-8 September). It included a visit to the cliffs of the English Channel as well as the rocks of the Jurassic and Cretaceous Periods of the Boulogne and Caen areas.

2. A study of the physical geography of the volcanic areas of the Central Massif, focusing on the chronology of the erosive processes, carried out by Michel-Lévy with the cooperation of the palaeontologist and archaeologist Marceline Boule (1861-1942), an assistant at the Paris Natural History Museum. This trip (30 August -8 September) was continued to Causses de Lozère, the Tarn Gorges (Gorges du Tarn), and L'Aigoual Massif, led by the forestry inspector, Alphonse Fabre.

\section{Excursions to the coalfields of Central France}

1. Houllières of Commentry and Decazeville (29 August-4 September), led by the mining engineer and director of the Com-

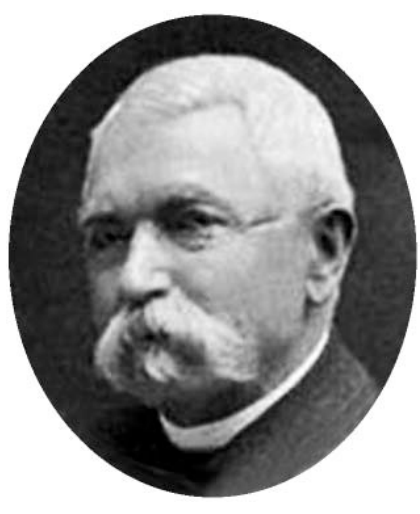

Figure 15 François Cyrille

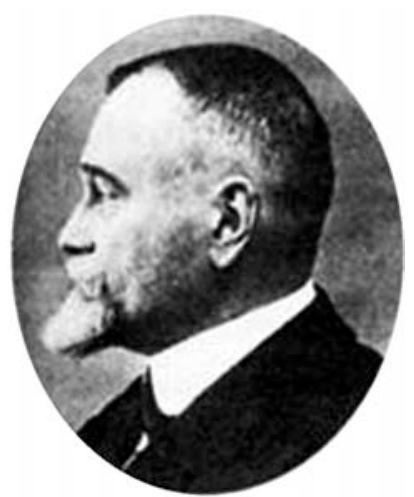

Figure 16 Émile Haug.
mentry-Fourchambault Society, Jules Henry Fayol (1841-1925).

2. The Loire coal basin (6-7 September), led by the local mining engineer and a pioneer of palaeobotany, François Cyrille Grand d'Eury (1839-1917) (Figure 15).

\section{Special excursions}

As well as the general excursions, other special scientific excursions were arranged as follows:

1. The Rhodano Tertiary basin and the Mesozoic and Cenozoic terrains of the Lower Alps. There were two excursions to these areas: (a) Rhodano basin (30 August-6 September), led by Charles Déperet (1854-1942), doctor and concurrent lecturer in geology in Marseilles and Lyon; (b) Digne-Siteron (7-11 September), led by Émile Haug (1861-1927), naturalist and authority on the tectonic structure of the Alps and professor at the Faculty of Sciences at Sorbonne University (Figure 16).

2. The Alps of the Dauphiné and Mont Blanc: Sub-Alpine ranges, the Belledonne ranges, La Grave, Gran Galibier, Mont Joly and Mont Blanc (31 August-9 September), led by Wilfrid Kilian.

3. Le Mure, Devoluy and Diois (3-12 September): the Palaeozoic of the La Mure massif and the Triassic of the Beauchaine subAlpine ranges, Dévoluy and the northeast of the Baronies region (Mesozoic and Cenozoic Periods), led by Pierre Lory (1866-1956), son of Charles Lory and Deputy Director of the geology laboratory at Grenoble University. This excursion was continued to Diois by Victor Pacquier; and to Cobonne (Livron) by the naturalist Gustave Sayn (1862-1933).

4. Mount Ventoux and Lure Mountain (12-20 September): the Urgonian of Mount Ventoux and the Barremian of Lure Mountain; fluvial terraces of Siteron and Apt, led by Killian and Léenhardt. This trip started with a reception held in the Grenoble Faculty of Science.

5. The Pelvoux massif and Briançonnais (30 August September): metamorphic and igneous rocks, with a study of Triassic and Liassic strata as well as the tectonic problems in the Pelvoux massif of the Hautes-Alpes, led by Pierre Termier (1859-1930), mining engineer, tectonicist, and lecturer at the École des Mines.

6. The Mont-Dore Massif, the Puys mountain range and Limagne (30 August-6 September): volcanoes and craters of the Clermont Ferrand area, the granites of d'Aydat, with the 'interlockings' of metamorphic rocks and the eruptive sequences of Mont Dore and other volcanic studies in the Puys region of Limagne. This work was led by Michel-Lévy.

7. The Morvan massif lying to the west of the Côte d'Or escarpment in Burgundy (29 August-8 September): Mesozoic of the Yonne Valley and the Alvalonnais region, Semur Liassic strata, the Morvan faults and volcanic formations, the Permian of d'Autun and the Chaume volcanic massif, led by the palaeontologist and retired Quartermaster General, Alphonse Peron (1834-1908), renowned for his knowledge of the stratigraphy and palaeontology of the Aumale region. This trip was continued through Avallonais, led by Charles Velain (1845-1925), pharmacist and lecturer in physical geography at Paris University.

8. Picardy (3-8 September): Picardy's Cretaceous phosphates and Quaternary sedimentary deposits in northern France, led by Gosselet, Cayeux and Ladrière.

9. The caves of the Causses region (29 August-4 September): the Palaeozoic scarps of Cévennes and the Causses plateau with its deep gorges, led by the pre-historian Eduard Alfred Martel (1859-1938).

10.The Black Mountain massif (29 August-6 September): Palaeozoic palaeontology and metamorphism of the Black Mountain; study of the various tectonic phenomena such as nappes, diverse fold-types, etc., led by the engineer Pierre Joseph Jules Bergeron (1853-1919), a lecturer in the Paris Faculty of Sciences. 


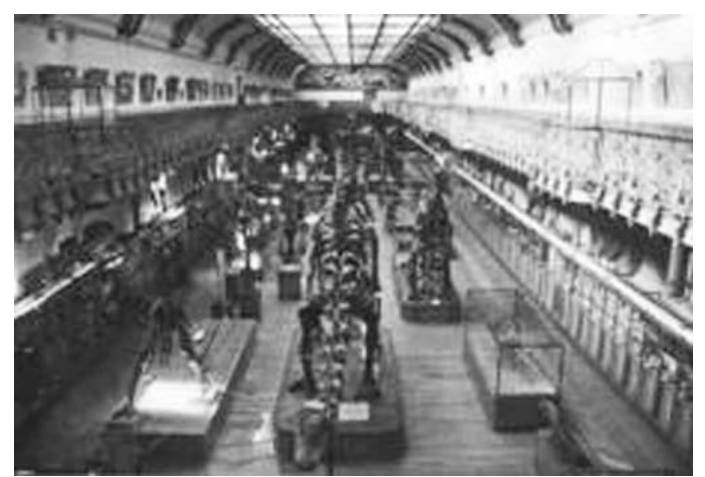

Figure 17 Palaeontology and Comparative Anatomy galleries, National Museum of Natural History, Paris.

11. Strato-sedimentary formations of the Pyrenees (30 August-8 September): Pyreneean stratigraphy, led by Léon Carez, author of Géologie des Pyrénées françaises (Paris 1903-1909).

12.Lower Provence (24 August-2 September): Toulon, Marseilles, Aix, and particularly the Bedoule and de Martigues deposits as well as the Cretaceous lacustrine rocks of the Flaveau Basin, led by the naturalist Gaston-Casimir Casseur (1855-1915), Marcel Bertrand, and Philippe Zurcher.

\section{Excursions during the Congress}

\section{Excursions in the Paris Basin (Tertiary deposits).}

1. 19 August: 1. Gisors, Mont-Javoult, Parnes (led by Munier Chalmas, Godin and Pezant); 2. Arcueil-Cachan, Bagneus and Bicêtre (led by Gustave Dollfus).

2. 20 August: 1. Beauvais and Pays de Bray (led by Chalmas).

3. 22 August: 1. Parc de Grignon (led by Stanislas Meunier); 2. D'Argenteuil (led by Léon Janet).

4. 24 August: 1. Montigny-sur-Loing (led by Léon Janet); 2. Cuisela-Motte (led by Munier Chalmas); 3. Étréchy, Jeur, Morigny and Étampes (led by Dollfus).

5. 26 August: 1. Auvers-sur-Ö̈se (led by Dollfus); 2. Mont Beron (led by Munier Chalmas); 3. Romainville (led by Léon Janet).

\section{Visits to Paris museums}

It is worth mentioning the visits made to the palaeontology and anatomy galleries of the Paris National Museum of Natural History on 18 August (Figure 17). The museum, founded by Albert Gaudry and George Pouchet, displayed a magnificent collection of fossils arranged from the oldest to the latest according to evolutionary principles. Gaudry, a convinced evolutionist and author of Les enchainements du monde animal dans les temps géologiques (1878-1890), presented his arrangement of fossils as a development of his evolu-

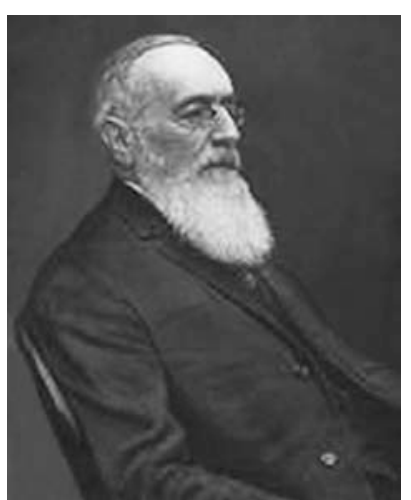

Figure 18 François Antoine Alfred Lacroix. tionary doctrine. This museum, designed by the architect Ferdinand Dutert, was opened in 1898 to be ready for the 1900 Universal Exhibition.

On 22 August, there were visits to the Mining Engineering School and the Catholic Institute and on 24 August to the geological sections of the Universal Exhibition. These visits were led by Launay, Raimond, and Thévenin. Finally, on 26 August, there were visits to the mineralogical sections, led by Alfred Lacroix (1863-1848) (Figure 18), and to the palaeontology sections, led by de Lapparent.

\section{CONGRES}

GEOLOGIQUE INTERNATIONAL se

VIII SESSION, EN FRANCE

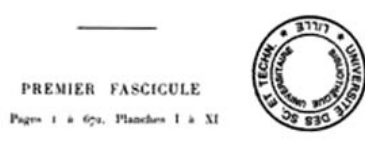

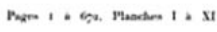

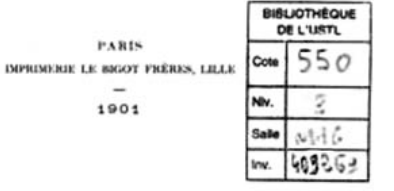

Figure 19 International Geological Congress: Comptes Rendus.

\section{The Congress}

\section{General data}

Although only a thousand people actually attended the Congress (and the Proceedings mention even less than that), it produced seventy-five published works by sixty-one authors, including papers and reports. The contents of the trips were published separately (Figure 19). As can be seen, around $30 \%$ of the papers corresponded to the host country, France, followed by those of Britain and North America with 6\% each. France, Great Britain and the United States accounted for over 50\% of the total of papers published (Figure 20). The rest of the countries had limited participation as far as papers presented were concerned.

The main subjects covered by the conference papers were: methodology and geological classification (13); geology of newly explored regions (12); experimental geology (5); palaeontological stratigraphy (8); orography (15); petrography (9); coal geology (5); volcanoes (2); glaciers (3); caves (2); applied geology (6); and hydrogeology (4). The most outstanding contributions were those in orography (18\%), methodology and geological classification (15\%) and exploration geology (15\%).

To take advantage of the Congress, some other related meetings were also held:

1. The European International Geological Map Commission, chaired by the German mining geologist Franz Beyschlag (1858-1914).

2. The Stratigraphical Classification Commission, chaired by the veteran Swiss geologist Eugène Renevier (1831-1906), lecturer at the University of Lausanne and President of the Zurich International Geology Congress (1894).

3. The Glaciers Commission, chaired by the Austrian geographer, historian and mountaineer Eduard Richter (1847-1905), from the university of Graz.

4. The Petrography Commission, with a final report presented by Lacroix.

5. A special commission for the publication of an international journal of petrography, chaired by the Austrian Friedrich Becke (1855-1931).

6. A special commission for the study of the project of the Institut Flottant International (International Oceanographic Institute), which had been proposed at St Petersburg and was accompanied by a report of the Russian Alexander Petrovich Karpinsky (1846-1936). In addition, they decided to organise subsequent meetings and to invite geographers and zoologists to participate 


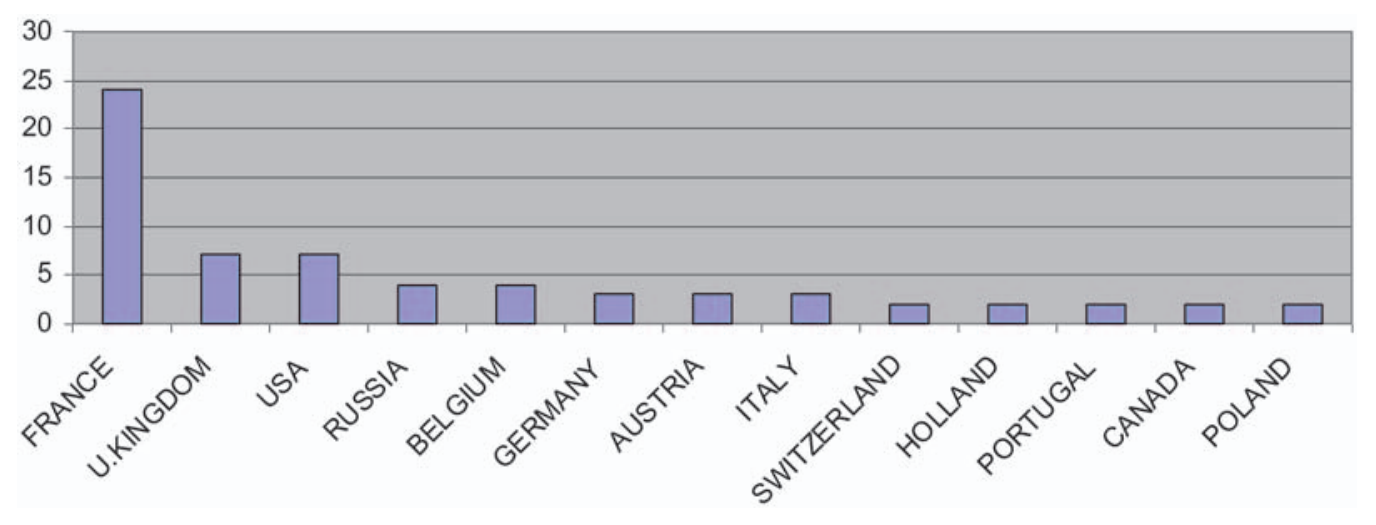

Figure 20 Distribution of Congress speakers according to countries.

in the research. However, the field of marine geology didn't really appear until Louis Dangeard (1898-1987) published his thesis at Sorbonne University (Observations de géologie marine et d'océanographie relatives à La Manche, 1929).

All contributions were published in French, the scientific language of the time.

\section{Geological progress around 1900 and the Paris International Geological Congress}

The main scientific advances in geology can be summarised as follows:

\section{Palaeontology}

Rules for the palaeontological nomenclature had been agreed upon at the Bologna International Geology Congress. Also, the number of species was reduced and a broader definition was established: "The species can present a certain number of alterations ... that will be shown by a third term preceded by, depending on the cases, the word Variety, Mutation or Form" (Gaudry, 1901, p. 129). Despite the advances in this field of palaeontology, there were other problems to be solved and it was at the Paris International Geological Congress when Kilian (following Oehlert) asked the Congress to publish a catalogue of synonyms for fossils and a synopsis devoted to distinguishing animal family group names, genus group names and species group names including fossil plants. He also requested the publication of images by means of pictures or engravings and holotypes that were in rare palaeontological works (Kilian, 1901). This was the starting point for a great international palaeontological work entitled Paleontologia universalis, the first fruits of which were distributed to the participants of Vienna International Geological Congress (1904).

As far as evolution was concerned, there was no debate, though Gaudry was one of the major figures present. From 1900 onwards and through different paths, the Dutch botanist Hugo de Vries (1848-1935), the North American geneticist Thomas Hunt Morgan (1866-1945) and others such as Tschermak, Bateson, Cuenot, Correns, etc. rediscovered Mendel's Laws. If, for Darwin, evolution involved a slow and gradual changes of hereditary characters, for Mendel, such hereditary characters had law-like combinations and were discontinuous in nature. So Darwinism per se was starting to fall into decline, being supplemented by genetics, though this did not influence the Congress.

As Armand Thévenin pointed out (1910), Gaudry held that all was harmony in the Universe, right from the age of the trilobites to the evolution of mankind. In the opening speech of the Congress, he affirmed that in order to recognise the plan which links us with Creation, there is a need to join the investigative efforts of everyone:
"Gentlemen, I believe that, because of you, this plan will eventually be realised". Gaudry's work projected itself in the coming years onto such authors as Frédéric Roman (1871-1943), author de Les transformations du monde animal (1907).

\section{Tectonics}

In 1873, the American geologist and mineralogist James Dwight Dana (1813-1895) established the geosyncline theory. In 1877, the Austrian naturalist Eduard Suess (1831-1914) published a work about the origin of the Alps called Die Entstehung der Alpen. Then, in 1897, Maurice Lugeon (1870-1953) established the various orogenic periods of the great foldings. It was the right time for largescale global tectonic texts.

There were, in fact, hardly any global tectonic works presented in the International Geology Congress. However, the conference contributed to the personal contact and information exchange among the tectonicists who were present, i.e. Bertrand, Termier, Haug, Huddleston, Hull, etc. Still, the most valued experiences for them were probably the excursions to the Pelvoux massif guided by Termier or those of Bertrand to the Pyrenees. There, in the Pyrenees, they were able to see nappes previously identified by Bertrand (1884) (cf. Dunbar, 1971). The term 'nappe' was proposed by Lugeon in 1902. In 1899, Jules Gosselet had acknowledged the existence of thrust folds (nappes de charriages) in the southern flank of the Black Mountain, where the excursionists had been.

\section{Physical geography (geomorphology)}

It was also the right time for the appearance of geomorphology. In 1885, the North-American geographer William Morris Davis (1850-1934), a lecturer at Harvard University, had proposed the concept of the 'cycle of erosion' (cf. Davis, 1885). He was the first to formulate a general theory about the origin of several landscapes features and he attended the Congress. It is worthwhile mentioning here the publication of Lapparent's work Leçons de géographie physique (1896), a book oriented to the 'géomorphogénie' of the various terrestrial kind of relief and also the foundation of the Chair of Physical Geography held by Charles Velain (1845-1925) in 1897. During the opening speech of the Paris Congress, Gaudry pointed out that the study of erosion (denudation) of the continental masses is a branch of geology. After giving some examples such as the Weald in England and the Grand Canyon and the Bad Lands of Nebraska in the United States, he concluded by saying: "There are great rock masses that have been denuded through the action of water". Archibald Geikie (1835-1924), formerly Professor of Geology at Edinburgh University and retiring as Director General of the Geological Survey of Great Britain in 1900, added in the conference: "[a]ccurate, systematic and continuous measurements are necessary in order to understand and appreciate the rapidity of denudations" (Geikie, 1901). The Congress organisers, aware of such scientific advances, 
organised an excursion to see the physical geography of the Central Massif.

\section{Experimental petrology}

Experimental petrology also reappeared at this time. In 1790, the Scottish geologist Sir James Hall (1761-1832) had observed how a slowly cooled glass mass crystallized. Also, a devitrified glass mass fragment that had been re-melted started to generate glass again after rapid cooling. Hall had accompanied Déodat Gratet de Dolomieu (1750-1801) on his expedition to Vesuvius and there he confirmed the glassy nature of lava. On the basis of these two observations, he decided to melt and devitrify rocks in 1797. Between 1878 and 1882, Ferdinand Fouqué (1828-1904) and Michel Lévy made experiments similar to those of Hall, studying the temperature of formation and the order of crystallization of rock minerals (Fouqué and Lévy, 1882). At that time, Vogt (1844-1888) was studying petrogenetic relationships in silicates and in 1884, Frederick Guthrie (1833-1866) used the concept of eutectic crystallization (a concept that would be replaced by Bowen with that of fractional crystallization). At the Paris Congress, there was a thematic section devoted to experimental geology, where a memoir by John Joly (1857-1933), lecturer at Dublin's Trinity College, is worth mentioning as it was one of the relevant works on the order of formation of silicates in igneous rocks: Mémoire sur l'ordre de formation des silicates dans des roches ignées.

\section{General petrology}

After Ferdinand Zirkel (1836-1912) published his Lehrbuch der Petrographie (1866) and Karl Harry Ferdinand Rosenbusch (1836-1914) published Mikroskopische Physiographie der petrographisch wichtigen Mineralien (1873), microscopic rock studies became more important, particularly in the field of igneous petrography. In France, Auguste Michel-Lévy published his Structure et classification des roches eruptives (1889), followed in Germany by Ulrich Grubenmann's (1850-1924) work in 1894 on metamorphic rocks Die cristallien Schiefer, and in 1897 (in France) by Lucien Cayeux's (1864-1944) work on sedimentary rocks Contribution à l'étude micrographique des terrains sédimentaires: l'étude de quelques dépôts silicieux secondaires et tertiaires du basin de Paris et de la Bélgique. In a few years, many advances had been made in microscopic mineral identification (e.g. Michel-Lévy's study of feldspars), textural studies and rock classification, and the genesis and age of rocks. In this context, Joseph Paxson Iddings (1857-1920) founded the first Chair of petrology in Chicago (USA) in 1892 (cf. Loewinson-Lessing, 1954).

A few months before the Congress, there had been a meeting of experts to prepare the event (25-26 October 1899), chaired by Michel-Lévy and some of the participants from such countries as Russia (Karpinsky, Loewinson-Lessing), Serbia (Zujovic), Norway (Brøgger) and Germany (Doelter), to name a few. One of the main concerns was to unify the vocabulary of petrology since ill-defined terms were being used, for example traps, porphyry, etc. Fedoroff, with the support of Geikie, Teall and Iddings, asked for the unification and standardisation of petrologic nomenclature, an issue that had previously been considered by a committee at the 7th International Geology Conference, at which an international commission for nomenclature was established. Before the commission's first meeting, Loewinsson-Lessing presented a questionnaire to the Russians with two main questions, as follows: (1) What guidelines should be established to rationalise petrographic nomenclature? (2) What are the shortcomings of the present-day nomenclatures? It was difficult to reach agreement, though members of the commission (Lagorio, Loewinsson-Lessing, Sederholm, and Ramsay) realised the need to simplify the terminology. As a basis for discussion, Loewinsson-Lessing's petrography nomenclature was printed for the meeting. He was a lecturer at Tartu University (Dorpat in German) in Estonia, who had devised a chemical classification of igneous rocks in his work Studien über die Eruptivgesteine (1897). For him, "chemical composition was the foundation for the classification of rock typology" (cf. Loewinsson-Lessing, 1901). According to Brøgger, chemical composition was closely connected with mineralogical composition. This and other meetings contributed to the creation of the 'CIPW norm' in 1902 in the United States, which influenced the work done in petrography for many years (Young, 2003).

However, the chemical classification of rocks was not very practical. Chemical analysis was at that time a lengthy and painstaking operation, which needed good equipment. According to Rinne (1912), data provided by chemical analysis were insufficient for rock identification. By getting to know a rock's mineralogy, its chemical composition could be inferred whereas a rock's mineralogy could not be deduced from its chemical composition. The French Petrography Commission had adopted the scheme for the classification of igneous rocks devised by Fouqué and Michel-Lévy in 1879. This classification was based on mineral composition and texture, both of which could be verified easily and quickly.

\section{Mineral Deposits}

Louis de Launay led a field trip to the Central Plateau of France in order to study its mineral deposits. He sought to study mineral deposits in their geological context (leur milieu original) and proposed the term 'metallogeny' in 1905 (Lagny, 2007).

Earlier in 1900, Eugène Fournier (1871-1941) had used the expression 'karst replacements' (replacements in karstic conditions). The same expression was adopted by Thévenin three years later, in his study of the Quercy phosphorites (Cayla, 2007).

At the time of the Congress the scientific community was starting to systematize the study of the genesis of the various types of mineral deposits.

\section{Conclusions}

1. The International Geology Congress held in Paris was a great success as far as attendance and participation were concerned. In fact, it was the most important congress held up to that time.

2. The organization of and participation in the Congress was multidisciplinary, including naturalists, geologists, mining engineers and other professionals working in the geosciences.

3. Although the Congress did not produce any profound scientific advances, the outcomes and decisions made contributed to the progress of palaeontology, petrography, and other branches of geology. It also gave an impetus to the fields of geomorphology, tectonics, and metallogeny.

4. There are few published studies of this Congress, but the relevant primary sources are readily available. Both the proceedings and contributions of the participants attest to the significance of this Congress for the development of geology.

\section{References}

Anonymous, 1899, Première circular du Congrès Géologique International de Paris, VIII Session: Bulletin de la Société Géologique de France, v. 26, pp. 10-17.

Anonymous, 1900, Excursion Guide VIII, Congrès Géologique International: Le Bigot frères. París \& Lille. Cf. Comptes rendus VIII Congrès Géologique International: Le Bigot frères, Paris \& Lille, v. 2, pp. 938-1002.

Anonymous, 1901, Allocution du Président: Bulletin de la Société Géologique de France, v. 28, pp. 799-801.

Cayla, N., 2007, La karstologie: Géochronique, no. 101, pp. 46-47.

Davis, W. M., 1885, Geographic classification, illustrated by study of plains, plateau and their derivates: Proceedings of the American Association Advancement of Science for 1884, v. 33, pp. 428-432.

Dunbar, C., 1971, La Tierra: Destino, Barcelona.

Ellenberger, F., 1978, The first International Geological Congress, Paris, 1900: Episodes, v. 2, pp. 20-24.

Fouqué, F. \& Michel-Lévy, A., 1882, Synthèse des minéraux et des roches: Masson, Paris. 
Fouqué, F. \& Michel-Lévy, A., 1879, Minéralogie micrographique: roches éruptives françaises (Mémoires pour servir a l'explication de la carte geologique detaillée de la France), A. Quantin, Paris.

Gaudant, J., 2007, La Société Géologique de France: Géochronique, no. 101, pp. 21-22.

Gaudry, A., 1901, Discours d'ouverture: Comptes rendus VIII Congrès Géologique International: Le Bigot frères, Paris \& Lille, v. 1, pp. 127-132.

Geikie, A., 1901, De la coopération international dans les investigations géologiques: Comptes rendus VIII Congrès Géologique International: Le Bigot frères, Paris \& Lille, v. 1, pp. 265-274.

Gómez Alba, J., 1992, Luis Mariano Vidal, 1842-1922. Biografía: generalitat de Cataluña-Museo de Geología de Barcelona-ITGE, Barcelona.

Guthrie, F., 1884, On eutexia: Philosophical Magazine, Series 5, v. 17, pp. 462-482.

Kilian, W., 1901, Sur deux projets tendant a faciliter les recherches paléontologuiques et géologuiques: Comptes rendus VIII Congrès Géologique International: Le Bigot frères, Paris \& Lille, v. 1, pp. 282-283.

Lagny, Ph., 2007, Les substances utiles: géochronique, no. 101, pp. 42-44.

Lapparent, A. de, 1896, Leçons de géographie physique: Masson, Paris.

Loewison-Lessing, F., 1901, Notice présenté a la Commission de nomenclature des roches, réuni en séance à Paris, le 25 octobre 1899: Comptes rendus VIII Congrès Géologique International: Le Bigot frères, Paris \& Lille, v. 1, pp. 218-226.

Loewinsson-Lessing, F. Y., 1954, A Historical Survey of Petrology: Oliver \& Boyd, Edinburgh \& London.

Rinne, F., 1912, Étude practique des roches: J. Lamarre \& Co., Paris.

Thévenin, A., 1910, Albert Gaudry: notice nécrologique: Bulletin de la Société Géologique de France, v. 1910, pp. 351-374.

Vai, G. B., 2004, The Second International Congress, Bologna, 1881: Episodes, v. 27, pp. 13-20.

Young, D. A., 2003, Mind over Magma: The Story of Igneous Petrology: Princeton \& Oxford, Princeton University Press.

Octavio Puche is a PhD Mining Engineer and is at present Professor of History of Geology and Mining at the Universidad Politéchnica de Madrid, Assistant Director of the Museo Histórico Minero D. Felipe de Borbón y Grecia (Madrid), and President of the Spanish Society for Geological and Mining Heritage (SEDPGYM). He is a recipient of the Research Award of his University for his work on investigations of mining heritage and the deterioration and conservation of stone.

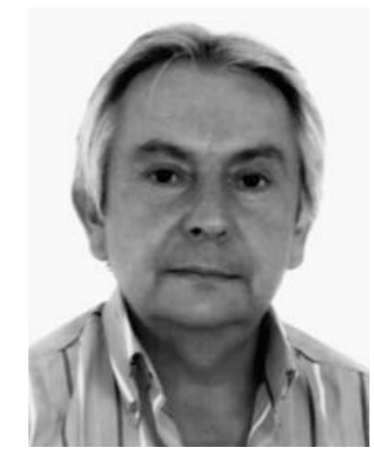

Luis F. Mazadiego is a PhD Mining Engineer and a professor at the Universidad Politéchnica de Madrid, editor of the SEDPGYM's journal De re metallica. He is a recipient of a Research Award from his University for his investigations in relation to oil and gas exploration in his field of organic geochemistry. He does research in the history of mining and geology.

Paz Kindelán is a lecturer in the Department of Linguistics Applied to Science and Technology at the Universidad Politéchnica de Madrid and at present is 'delegated director' in the Department of Linguistics at the School of Mining Engineering. She is particularly interested in engineering education, the role of research and researchers in the new context of internationalisation, and the acquisition of knowledge in specific situations and specific cultures.
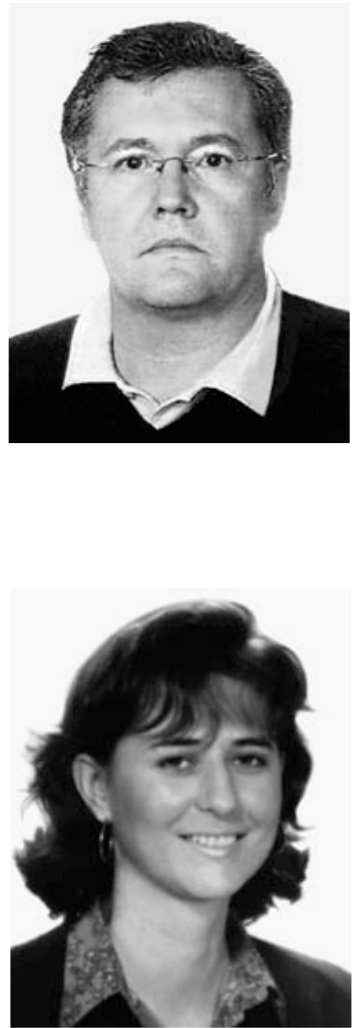